E Q U I L I B R I U M

Volume 6 IsSue 3, 2011

IS S N $1689-765 \mathrm{X}$

\author{
Ali T. Akarca \\ University of Illinois at Chicago, United States
}

\title{
INTER-Election Vote SWINGS FOR the Turkish Ruling Party: the Impact of Economic Performance and Other Factors*
}

\section{JEL Classification Codes: $D 72$}

Keywords: elections; vote swing; economic voting; economic performance; AKP; Turkey

\begin{abstract}
Inter-election vote swings for the AKP, the incumbent party in Turkey, during 2002, 2004, 2007, 2009 and 2011 elections are decomposed into parts attributable to economic conditions, strategic voting, cost of ruling, incumbency advantage, political realignment and other factors. For this purpose a vote equation, fitted to data covering twenty-seven National Assembly, Senate, and Provincial Council elections, held between 1950 and 2011 is used. The results show the pivotal role played by the economy on the political fortunes of incumbent parties.
\end{abstract}

\section{Introduction}

It is generally accepted that economic performance is critical to political fortunes of the incumbent parties. Indeed, the short history of the Justice and Development Party (AKP), the ruling party in Turkey, would attest to that. The party was formed in 2001, the year in which the country experienced its severest economic crisis in the last half a century and sixth decline in per capita real GDP in fourteen years. It came to power the following year in an election, which ousted all

* Earlier versions of this paper were presented at the 6th International Conference on Contemporary Issues in Economy: After the Crisis, held at Nicolaus Copernicus University, Torun, Poland, 13-14 May 2011, the Anadolu International Conference in Economics (EconAnadolu) held at Anadolu University, Eskişehir, Turkey, 15-17 June 2011, and the 41st Annual Meeting of the Illinois Economic Association, held at DePaul University, Chicago, Illinois, USA, 28-29 October 2011. I have benefited greatly from the comments I have received from the audiences at these meetings. 
of the political parties that entered the parliament in the previous election. The party's vote share kept increasing, from 34.3 percent in 2002 to 41.7 and 46.6 percent, respectively, in the 2004 local administrations, and 2007 parliamentary elections, as the economy boomed and inflation rate dropped. Then in the 2009 local administrations election, the party suffered its first vote loss, when the global economic crisis hit the country. The party's vote share dropped to 38.4 percent. With the economy out of crisis and humming again, the AKP raised its vote share to 49.9 percent in the 12 June 2011 parliamentary election. Thus, there is at least anecdotal evidence linking economic and political performances in the Turkish case. However, obviously the economy is not the only factor that affects the electoral outcomes. Consequently, to understand and assess the impact of the economy on electoral outcomes properly, one needs to identify the main factors, which play a role, and measure the influence of each, controlling for those of the others. The purpose of the present study is to do exactly that. First, an equation is developed building on the works of Akarca and Tansel (2006) and Akarca (2009, 2010 and 2011), to capture the behavior of the Turkish voters. Then with the help of this model, the inter-election vote swings for the AKP are decomposed into parts attributable to various causes.

The model in question takes into account the main factors mentioned in the economic voting literature ${ }^{1}$. However, it also considers the major political realignments that have taken place in Turkey. Thus, a brief discussion of both the economic voting literature and the political realignments would motivate the model used in the decomposition of vote swings. The next section does that. In section 3 , the vote equation is fitted to data, and is converted into vote swing form. Then in section 4 , the latter is utilized to measure the effects of various variables on the changes in the AKP vote share from one election to another, during 2002-2011. Finally, in the last section, conclusions are summarized. These are relevant not only to the Turkish case but also in the cases of other countries as well, since the behavior of Turkish voters is not that different from that of their brethren in other parts of the world ${ }^{2}$.

${ }^{1}$ Understanding the behavior of voters is the key to predicting and interpreting such things as election outcomes, longevity of governments, election timing, political fragmentation, and political business cycles. Consequently, a field has developed over the last four decades or so, analyzing how voters vote, referred to as economic voting. Lewis-Beck and Paldam (2000) define it as "a field that mixes economics and political science and does so by means of econometrics." Detailed surveys of this literature are provided by that study, Lewis-Beck and Stegmaier (2000), and Akarca and Tansel (2006 and 2007).

${ }^{2}$ Akarca and Tansel (2006) compare the behavior of Turkish voters to that of voters in other countries. 


\section{Determinants of vote swings}

According to the literature on economic voting, most voters align themselves with a party that they identify as representing their interests and ideology. Thus, they show a tendency to choose the same party they voted for in the previous election. This creates a great amount of inertia in the political system. However, the vote shares of political parties fluctuate due to the combined effects of strategic voting by the electorate, depreciation in the political capital of the incumbent party (cost of ruling), incumbency advantage, the economy, and other factors. In some cases, as in Turkey, in addition to the transitory deviations caused by the forces mentioned, one needs to consider massive shifts in party allegiances (political realignments) that occur from time to time.

\section{Strategic voting}

In every election, a portion of the electorate votes for a party other than their first choice. In other words, they vote strategically. They behave this way mainly for two reasons: to check the power of the incumbent party and to avoid wasting their vote by voting for a party which is not likely to surpass the national threshold necessary to gain representation. In elections, such as midterm congressional elections in the U.S., European Parliamentary elections in European Union countries, and local administrations or parliamentary by elections in Turkey, supporters of the incumbent party get a chance to check the power of the central government, without toppling it. Then, even more of them vote with the intention of diluting the power of the government. Consequently, incumbent parties tend to do poorly in these types of elections. Existence of threshold regulations in parliamentary general elections, such as the minimum 10 percent nationwide vote share requirement to gain representation in the Turkish Grand National Assembly, contributes to this effect as well. Some of the small party supporters, who had voted strategically for one of the major parties in the previous domestic parliamentary election, not to waste their vote, return to their first choices in elections where no such handicaps apply, such as local administrations elections in Turkey. On the other hand, in a parliamentary election, with the control of government at stake, the incumbent party will experience fewer deserters. Furthermore, the party will attract some supporters from its smaller ideological cousins as well, who fear wasting their votes if they vote for their first choices. Therefore, holding other factors constant, we should expect the vote losses of the incumbent party, due to strategic voting, to be higher in a local administration election following a parliamentary one, and lower in a parliamentary election following a local administration election, and to be in between these when the two elections involved are of the same type. Incumbent party vote losses due 
to strategic voting in parliamentary by elections should be even greater than in local elections, as not even the control of local administrations are at stake then. We should further note that, other things being equal, vote losses due to strategic voting is likely to be larger the higher is the incumbent party's previous vote share. In other words, the more you have, the more you stand to lose.

\section{Cost of ruling}

Ruling involves making some compromises and unpopular or bad decisions, and shelving some promises. These cost incumbent parties votes as well. The "cost of ruling", as some refers to it in the literature, rises with the time spent in power, as disappointments with the incumbent parties accumulate. Besides time in power, the size of the initial political capital matters as well.

Losses would be bigger when the previous vote share is higher. Again, having more leads to losing more.

\section{Incumbency advantage}

Incumbency has its advantages too, and it can offset part of the losses due to strategic-voting and cost of ruling. Besides things like access to the media and name recognition, the incumbency advantage includes things like ability to indulge in transfer activities such as providing services, subsidies and patronage, and picking locations of government investment and public work projects, to attract supporters of other parties.

\section{Economic conditions}

The voters reward incumbents for a good economic performance, and punish them for a bad one. However, in making their economic evaluations, they tend to be retrospective and myopic. They look back no more than a year or so. They also place more weight on growth than inflation. Such voter behavior gives incentives to governments to conduct expansionary economic policies before an election and then switch to restrictive policies after the election to counter their inflationary effects. It also induces governments to postpone adjustments needed for the economy at least until after elections. In short, the behavior of the voters may be at the root of political business cycles observed in so many countries. Voters judge governments ego-tropically as well as socio-tropically. That is, they consider not only changes in their own economic well-being but others' as well. The latter may be out of concern for their fellow compatriots but also because they may be using government's nationwide performance as an indicator of its competence. 


\section{Political realignments}

When party choices denied to them before become available, when the needs and outlook of voters change but their parties fail to adapt, or when their parties change in a manner that deviates from their interests and beliefs, voters shift their allegiances to other parties. These occur infrequently and involve large and permanent vote movements in contrast to the marginal and transitory changes discussed in the previous four subsections. Five such realignments have taken place in Turkey since it entered multi-party democracy in 1946.

The first realignment occurred between 1946 and 1950 (and perhaps extended toward 1954) when the country entered the era of multi-party democracy. Then, large amount of votes shifted from the Republican People's Party (CHP), the sole party allowed since 1924, to the new Democrat Party (DP1) ${ }^{3}$. Since this period lies outside the sample period examined in the present study, it is not necessary to discuss it here in detail ${ }^{4}$.

A realignment, which occurred during 1961-1963, did not involve a major incumbent party, and thus not considered in the vote equation. Then the votes of the DP1, which was closed by the junta leaders after they took over the government in 1960, split between Justice Party (AP) and the New Turkey Party (YTP). This occurred because the voters were confused initially as to which of the two parties stood for the values espoused by the DP1, as making such claims by political parties was banned. Later these votes coalesced in the AP.

A much smaller and shorter-lived realignment has occurred between 1973 and 1975. Before the 1973 election, a political faction split from the Justice Party, the major incumbent party then, and formed the Democratic Party (DP2). This new party siphoned off considerable amount of votes from the AP in the 1973 election, as most supporters of the party was confused as to which of the two parties really represented their worldview and interests. However, these votes largely returned to the Justice Party in the following election in 1975 and the DP2 virtually disappeared from the political scene after that.

The military junta, which took over the government in 1980, banned all political parties. Only one new left wing and two new right wing parties were permitted to enter the 1983 election. Consequently, the latter two, the Motherland Party (ANAP) and the Nationalist Democracy Party (MDP) shared the supporters of the previous right wing parties: the AP, National Salvation Party (MSP) and the

${ }^{3}$ Since 1946, three parties had the acronym DP. To avoid confusion, the first of these, the Democrat Party, which existed in the fifties will be referred to as DP1, and the second one, the Democratic Party, which existed in the seventies will be referred to as DP2, and the last one, Democrat Party still in existence as DP.

${ }^{4}$ The 1946 election is excluded because it is considered unfair. The outcome of the 1950 election is used in estimating the vote equation presented in section 3 , but as a value for the lagged dependent variable, which enters the model as an independent variable. 
Nationalist Action Party (MHP). After the successors of the latter three parties were able to enter the political arena in 1984, they siphoned off many voters from the ANAP. However, while the ANAP was shedding votes to these parties it captured almost equivalent amount of votes from the MDP as this party disintegrated. For that reason, the parameter estimates of the variables included in the vote equation to measure this realignment, proves to be statistically and literally insignificant.

The last realignment, which manifested itself after 1999, but in hindsight appears to have begun earlier, is of the greatest importance for the current study. After experiencing rampant corruption, constant infighting, and four economic crises under various coalition governments during the preceding decade, in the November 2002 election, voters ousted all of the parties, which had entered the parliament in 1999. Major incompetence and rampant corruption exposed by the two major earthquakes in 1999, implicating both the government and the opposition parties may have acted as the straw that broke the camel's back ${ }^{5}$.

The parties ousted from the Turkish parliament in 2002 were who's who of Turkish politics. Among them were the ANAP, which held the premiership during 1983-1991 and 1997-1999, the True Path Party (DYP) and the Democratic Left Party (DSP), which led governments during 1991-1996 and 1999-2002, respectively, and the Nationalist Action Party (MHP), which was part of the ruling coalition between 1999 and 2002 together with the DSP and the ANAP. None of them was able to surpass the ten percent nationwide vote share threshold necessary for representation in the Turkish Grand National Assembly. The Constitutional Court had already banned the Virtue Party (FP) in 2001. The predecessor of this party, the Welfare Party (RP), held the premiership during 1996-1997. The combined vote share of the parties mentioned was 81 percent in 1999 but only 24 percent in 2002 . Only 11 percent of the legislators elected in 1999 made it to the 2002 parliament.

The AKP, which emerged from the ashes of the banned FP, captured the lion's share of the voters who deserted their former parties. The party's disavowal of its Islamist roots, embrace of political and economic reforms necessary for Turkey's accession to the European Union (EU), the non-corrupt and populist image of its mayors at the local level, its message of hope, and the likelihood of it forming a single-party government, all appealed to the electorate which deserted the rightwing ANAP, DYP and MHP ${ }^{6}$. The Felicity Party (SP), the other party rooted in

${ }^{5}$ According to literature on corruption, it appears that voters react to corruption drastically only when, the corruption is massive, the information on it is highly credible and well publicized, it implicates political parties across the board, and not accompanied by otherwise competent and beneficial governance. Chang et al. (2010) and Ferraz and Finan (2008) provide evidence on that from Italian and Brazilian cases.

${ }^{6}$ For more details on the sources of the AKP votes the reader is referred to Başlevent and Akarca (2009) and Akarca and Başlevent (2009). 
the FP, towed the old party line and received only a couple of percent of the votes.

The shift of votes from the ANAP and DYP (now DP) towards the AKP continued after 2002. In the ongoing power struggle between elected officials, and bureaucratic and military establishment, since the beginning of the republic, these two parties come from the tradition of siding with the former. When their new leadership relinquished this position, and continued taking stands in this regard that are not popular with their remaining supporters, they continued to lose their base to the AKP and other parties. The way the AKP conducted itself in power facilitated this vote transfer as well. Despite the Islamist background of many of its leaders, the party ruled essentially as a moderate, center-right, conservative democrat party would: committed to democracy, free market economy and Turkey's EU membership. This dispelled some of the lingering skepticism concerning the genuineness of the party leaders' transformation, and led more of the liberal minded voters to support it. Interestingly, the party was able to do all that without alienating much of its traditional base. Over the last two decades, that base, while holding on to its basic conservative values, got increasingly richer, better informed, more entrepreneurial, more modernized, more urbanized, and more integrated with other parts of Turkey and the rest of the world. These occurred largely as the result of the introduction of internet, ending of the state monopoly on television and radio, major improvements in the transportation and telecommunication systems, and the market-oriented reforms instituted in the eighties by Turgut Özal, the prime minister then. The leadership of the AKP recognized this evolution in the society well and changed, while other parties did not. We can say that the AKP captured the supporters of the ANAP and DYP because these parties changed, and the supporters of the FP because this party's successor, the SP, failed to change.

In short, a mass shift in votes has occurred between 1999 and 2011, which was far more than what could be attributed to the usual factors of strategic voting, cost of ruling, or voter response to economic conditions. At the end of this process, of the parties left out of the parliament in 2002, only the MHP was able to engineer a comeback. By 2011, the rest and the Young Party (GP), which emerged in 2002, disappeared either literally or for all practical purposes. Their combined vote share declined from $63 \%$ in 1999 to $23 \%$ in 2002 and to $2 \%$ in 2011. 


\section{The model}

A vote equation, which accounts for all of the factors mentioned in the previous section, is the following:

$$
\begin{gathered}
V_{t}=a+b V_{t-k}+c \Delta L_{t} \cdot V_{t-k}+d \Delta B_{t} \cdot V_{t-k}+f D 02_{t} \cdot V_{t-k}+h D 04-11_{t} \\
S_{t-k}+m D 73_{t} \cdot V_{t-k}+n D 75_{t} \cdot Q_{t-k}+u r_{t} \cdot V_{t-k}+v g_{t}+w p_{t}+e_{t}
\end{gathered}
$$

where $\Delta X_{t}=X_{t}-X_{t-k}$, and the variables are defined as follows:

$V_{t} \quad-$ vote share of the major incumbent party in election held at time $\mathrm{t}$,

$V_{t-k} \quad-$ vote share of the major incumbent party in the previous election held

k $\quad-$ years earlier,

$L_{t} \quad-$ a dummy variable, which takes on the value of one if the election in volved is for local administrations, and zero otherwise,

$B_{t} \quad-$ a dummy variable, which takes on the value of one if the election in-volved is a National Assembly by-election only (that is, not held simultaneously with a Senate election), and zero otherwise,

$D 02_{t}-$ a dummy variable, which takes on the value of one in 2002, and zero in all other years,

D04-11 $1_{t}$ - a dummy variable, which takes on the value of one between 2004 and 2011, and zero in all other years,

$D 73_{t}$ - a dummy variable, which takes on the value of one in 1973, and zero in all other years,

$D 75_{t}$ - a dummy variable, which takes on the value of one in 1975, and zero in all other years,

$S_{t-k} \quad-$ he aggregate vote share of the independent candidates and the right-wing parties other than the AKP, in the previous election (or aggregate vote share of all parties except CHP, DSP and the ethnic Kurdish party, in the previous election),

$Q_{t-k} \quad-$ vote share of the Democratic Party (DP2) in the previous election,

$r_{\mathrm{t}}-$ number of years the major incumbent party was in power since the previous election,

$g_{t} \quad-$ growth rate of the per capita real GDP during the four quarters preceding the election held at time $t$ (henceforth referred to as the growth rate),

$p_{t} \quad-$ inflation rate in GDP implicit price deflator during the four quarters preceding the election held at time $t$ (henceforth referred to as the inflation rate).

The parameter, a, represents the incumbency advantage, 1-b, losses due to strategic-voting in parliamentary general elections, $\mathrm{c}$ and $\mathrm{d}$, the additional losses due to strategic-voting in local administration and parliamentary by elections re- 
spectively, $\mathrm{u}$ the cost of ruling per year, and $\mathrm{v}$ and $\mathrm{w}$, the effects of economic conditions. The coefficients $\mathrm{f}$ and $\mathrm{m}$ capture the unusual proportion of supporters the incumbent parties lost in 2002 and 1973 respectively due to political realignment. On the other hand, $h$ measures the proportion of the remaining supporters of other right-wing parties captured by the AKP in elections held after 2002, and $\mathrm{n}$ measures the proportion of Democratic Party (DP2) votes, which returned to the AP in 1975.

Table 1 presents the Ordinary Least Squares estimates of the parameters of equation (1). Also included in the table are the $t$-statistics for the parameter estimates, the $R$-square, the adjusted $R$-square, and $F$ values, for judging the fit of the equation, and Durbin's (1970) $h$ and White's (1980) chi-square statistics and their probability values to check for autocorrelation and heteroskedasticity in the residuals and any misspecification in the equations considered. The equation fits the data very well. The data used in fitting the equation is presented in the appendix, with more precise information on how the variables are defined and measured.

Substituting the parameter values in table 1 and deducting $\mathrm{V}_{\mathrm{t}-\mathrm{k}}$ from both sides of the equation, the above vote equation can be expressed as a vote swing equation:

$$
\begin{aligned}
& \Delta V_{t}=7.802-0.132 V_{t-k}-0.053 \Delta L_{t} \cdot V_{t-k}-0.128 \Delta B_{t} \cdot V_{t-k}-0.679 D 02{ }_{t} \cdot V_{t-k} \\
& +0.175 D 04-11_{t} \cdot S_{t-k}-0.149 D 73_{t} \cdot V_{t-k}+0.688 D 75_{t} Q_{t-k}-0.055 r_{t} \cdot V_{t-k} \\
& +0.774 g_{t}-0.128 p_{t}+e_{t} \\
& \text { where } \Delta V_{t}=V_{t-}-V_{t-k} \text {. }
\end{aligned}
$$

Equation (2) estimates the incumbency advantage as 7.8 percent of the total votes in every election. According to the equation, the major incumbent party is expected to lose on the average 13.2 percent of its vote in the previous election of the same type due to strategic voting of a portion of the electorate. This loss will be 18.5 percent in local administrations and 26 percent in parliamentary by elections that follow a parliamentary general election, and 7.9 percent in a parliamentary general election that follows a local administrations and 0.4 percent in parliamentary general election that follows a parliamentary by election. In a parliamentary by election following a local administration election however the loss due to strategic voting should be about 20.7 percent. In addition, the major incumbent party's vote share is likely to depreciate at the rate of 5.5 percent per year while in office.

The political realignment has cost the DSP, the major incumbent party in 2002, about 68 percent of its support, over and above what it lost due to other factors. The AKP on the other hand appears to have captured in each election after 2002, about 17.5 percent of the remaining supporters of the other right wing parties and the independents. It appears that the fragmentation of the major in- 
cumbent party in 1973 cost it about 15 percent of its supporters, but the party essentially got them back in 1975 .

The estimated equation indicates also that each percentage point increase in the growth rate of per capita real GDP during the one-year period before the election, will raise the share of the major incumbent party in the total vote by 0.77 percentage points. Each percentage point increase in the inflation rate during the same period, on the other hand, lowers this share by 0.13 percentage points or by about one-sixth of that of the growth rate. Thus, an incentive exists for Turkish governments to adopt populist policies before elections especially considering the fact that economic conditions prevailing more than a year before the election does not matter ${ }^{7}$. As long as it does not generate an additional inflation exceeding about 6 percentage points, a stimulation of the economy that results in a percentage point increase in the growth rate is advantageous to the main incumbent party.

\section{Decomposition of vote swings for the AKP}

In table 2, using the parameter estimates obtained in the previous section and the data given in the appendix, inter-election vote swings for the AKP during 20022011 is broken down into parts due to each of the determinants listed in section 2. The difference between sum of these and the actual vote swing captures errors in the estimation of parameters and measurement of variables, but also factors unique to the particular elections involved, and is labeled "other or error."

The patterns emerging from table 2 are that strategic voting mattered most in local administration elections in 2004 and 2009, cost ruling was highest in 2007 when the election was held more than three years after the previous election, and lowest in 2004, when the election took place only a little more a year after the one in 2002. At face value, economic conditions seem to be not as important as the other factors, but that misses the pivotal role played by the economy. Among the determinants of vote swings, the economy is the only one that can have a positive or negative effect. The effects of strategic voting and cost of ruling are always negative, whereas that of incumbency advantage is always positive. The latter offsets the first two considerably, but usually not completely. Ignoring political realignments, which are extraordinary events, a good economic performance is the only way to close the gap. We should note that, in table 2, in all elections for which the vote swing was positive, the economic growth was positive as well.

${ }^{7}$ Statistical evidence for the existence of myopia in Turkish voters was provided in Akarca and Tansel (2006 and 2007) and thus not checked again in the current paper. 
However, even a relatively good performance, by itself, often is not sufficient to avoid a decline in the ruling party's vote share. For example, the vote share of the AKP would not have increased in 2004 and 2007 had political realignment was not taking place then, despite reasonably good economic performances. In 2011, the vote swing would still be positive, even in the absence of a favorable political realignment. That was the case because in 2011 the economic growth was exceptionally high, inflation unusually low, and vote losses due to strategic voting quite small, with the contest being a parliamentary election following a local one.

In general, it is far more likely for an incumbent party to lose votes between two parliamentary elections than to gain. The ruling party is likely to lose even more votes between a parliamentary election and a local administrations election. When the AKP raised its vote share in 2007, relative to 2002, it became the first party in Turkey since 1954 to increase its vote share between two parliamentary elections, after ruling a full legislative term. When in 2004, it managed to raise its vote share relative to 2002, it became the second Turkish party since 1963 (the year when local elections began to be held nationwide simultaneously) to increase its votes in a local administrations election, relative to the previous parliamentary election. Actually, if the 1977 local administrations election, which took place only a few months after a parliamentary election is set aside, 2004 was the first time this has happened in Turkey. When the AKP increased it vote share in 2011 relative to both 2009 and 2007, it became the first party to raise its votes after remaining in power for two consecutive legislative terms. The fact that these events have occurred so rarely - once per half a century or so - should be sufficient to realize how difficult it is, in a democracy, for a political party to remain in power for a long time without interruption. Barring extraordinary instances such as voters changing their allegiances en masse, an incumbent party can raise its vote share only if its economic performance is unusually good. In the absence of an exceptionally good economy and political realignment, an incumbent party would face a decline in its vote share and can maintain its power more than one term only if its initial support was quite high.

Table 3 demonstrates the pivotal role the economy plays even more clearly. The table, obtained by taking differences between adjacent rows of table 2, helps explain what has changed since the last election, to cause a change in the incumbent's vote swing. For example, vote swing was 4.9 points in 2007 , but -8.2 in 2009, a difference of about 13 points. To what extent this fluctuation resulted from fluctuations in the economy. The fact that per capita income rose 4.7 percent prior to the 2007 election and fell 5.7 percent prior to the 2009 election accounts for 8 of the 13 point difference in vote swings. In other words, had the economy been growing in 2009, at the same rate as it was in 2007, the voters would have rewarded the AKP by raising its vote share by 3.6 percentage points, instead of punishing the party by reducing its vote share by 4.4 percentage 
points. Similarly, if in 2011, if the growth rate was as it was in 2009, instead of being rewarded 5.7 points by the voters, the AKP would have been penalized 4.4 points. About half of the difference in vote swings between 2009 and 2011 can be attributed to the difference between the growth rates. It appears that whenever there was a major fluctuation in the incumbent party's political fortunes, wide fluctuations in the economy was at the heart of it.

\section{Conclusions}

Although there are factors other than the economy, which influence the magnitude of the vote swing for the incumbent party, their effects largely offset each other. However, there is a tilt in favor of those exerting a negative impact. Consequently, in the absence of a very good economic performance, the ruling party is very likely to lose votes. This gives economic conditions a pivotal role in the determination of political fortunes. Barring extraordinarily favorable events (such as a political realignment), improving the economic well-being of the voters substantially is the only way a ruling party can close the gap between negative and positive influences of non-economic factors. This is especially true in elections, like the ones for local administrations in Turkey, when the gap in question becomes particularly large, due to strategic voting being especially unfavorable for the incumbent party. Then even a relatively good economic performance may not be enough to plug the gap completely. When such elections coincide with an economic crisis, their outcome would be detrimental for the party in charge. That is what happened to the AKP in 2009. On the other hand, with a parliamentary election following a local one, and the economy doing exceptionally well, the party raised its vote share again in 2011. Although the political realignment occurring played a role in this, the economic performance alone was sufficient to surpass the difference between incumbency advantage and the sum of strategic voting and cost of ruling. The party in 2011 raised its vote share relative to the previous parliamentary election held in 2007 as well and by doing so, renewed a record and broke another. The AKP became the first Turkish party since 1957 to win a third consecutive term and the first Turkish party ever to raise its vote share second time in a row between two parliamentary elections. However, in the absence of the political realignment going on at the time, the economic performance, despite being exceptionally good, would not have been sufficient to accomplish the latter. The vote losses suffered by the incumbent party, due to strategic voting and cost of ruling, is much higher between two parliamentary elections than between a local and a parliamentary election. A good economic performance stands a chance to compensate the latter but not the former. 
Table 1. Estimated vote equation

\begin{tabular}{|c|c|}
\hline Variables & Coefficient estimate \\
\hline Constant & $\begin{array}{l}7.802 \\
(1.72)\end{array}$ \\
\hline $\mathrm{V}_{\mathrm{t}-\mathrm{k}}$ & $\begin{array}{c}0.868 \\
(9.29)\end{array}$ \\
\hline$\Delta \mathrm{L}_{\mathrm{t}} \cdot \mathrm{V}_{\mathrm{t}-\mathrm{k}}$ & $\begin{array}{r}-0.053 \\
(2.71)\end{array}$ \\
\hline$\Delta \mathrm{B}_{\mathrm{t}} \cdot \mathrm{V}_{\mathrm{t}-\mathrm{k}}$ & $\begin{array}{c}-0.128 \\
(4.14)\end{array}$ \\
\hline $\mathrm{D} 02_{\mathrm{t}} \cdot \mathrm{V}_{\mathrm{t}-\mathrm{k}}$ & $\begin{array}{c}-0.679 \\
(4.59)\end{array}$ \\
\hline D04-11.$S_{t-k}$ & $\begin{array}{l}0.175 \\
(3.28)\end{array}$ \\
\hline$D 73_{t} \cdot V_{t-k}$ & $\begin{array}{l}-0.149 \\
(2.08)\end{array}$ \\
\hline $\mathrm{D} 75_{\mathrm{t}} \cdot \mathrm{Q}_{\mathrm{t}-\mathrm{k}}$ & $\begin{array}{l}0.688 \\
(2.74)\end{array}$ \\
\hline$r_{t} \cdot V_{t-k}$ & $\begin{array}{l}-0.055 \\
(3.46)\end{array}$ \\
\hline$g_{t}$ & $\begin{array}{c}0.774 \\
(4.34)\end{array}$ \\
\hline $\mathrm{p}_{\mathrm{t}}$ & $\begin{array}{l}-0.128 \\
(3.51)\end{array}$ \\
\hline $\begin{array}{c}\mathrm{F} \\
\text { Prob }>\mathrm{F}\end{array}$ & $\begin{array}{c}66.44 \\
0.00\end{array}$ \\
\hline $\begin{array}{l}\text { Durbin-h } \\
\text { Prob }>\mathrm{h}\end{array}$ & $\begin{array}{c}-1.07 \\
0.14\end{array}$ \\
\hline $\begin{array}{l}\text { White Chi-square } \\
\text { Prob }>\text { Chi-square }\end{array}$ & $\begin{array}{c}26.99 \\
0.67\end{array}$ \\
\hline $\begin{array}{c}\text { R-square } \\
\text { Adj. R-square }\end{array}$ & $\begin{array}{l}0.98 \\
0.96\end{array}$ \\
\hline
\end{tabular}

Table 1 notes: The dependent variable in the regression is $V_{t}$, the vote share of the sole incumbent party in case of single-party governments and of the major incumbent party in case of coalitions. For the definitions of variables, see Section 3, and for their measurement, the notes to the Appendix table. The data covers 27 local and parliamentary elections between 1951 and 2011. The Ordinary Least Squares method is used in the estimation of equations. The dark-gray shaded cells indicate significance of the parameter estimate at one percent level, medium-gray shaded cell at five percent and the light-gray shaded cell, at ten percent level, in one-tailed tests.

Source: Author's computations using the data given in the appendix. 
Table 2. Sources of vote swings

\begin{tabular}{|c|c|c|c|c|c|c|c|c|}
\hline 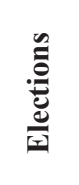 & $\begin{array}{l}00 \\
0 \\
0 \\
0 \\
0 \\
0 \\
0\end{array}$ & 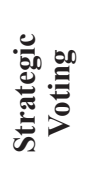 & 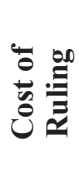 & 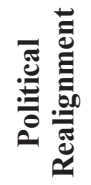 & 苞 & 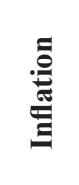 & 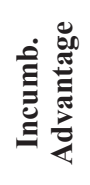 & 氙 \\
\hline 2004 & +7.39 & -6.34 & -2.36 & +6.81 & +3.41 & -2.41 & +7.80 & +0.48 \\
\hline 2007 & +4.91 & -3.29 & -7.45 & +5.75 & +3.64 & -1.15 & +7.80 & -0.39 \\
\hline 2009 & -8.19 & -8.62 & -4.48 & +5.02 & -4.41 & -1.70 & +7.80 & -1.80 \\
\hline 2011 & +11.44 & -3.03 & -4.75 & +5.25 & +5.73 & -0.84 & +7.80 & +1.28 \\
\hline
\end{tabular}

Source: Author's computations using parameters estimates in table 1 and the data in the appendix.

Table 3. Sources of differences in vote swings

\begin{tabular}{|c|c|c|c|c|c|c|c|c|}
\hline 莺 & 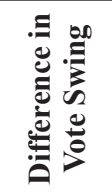 & 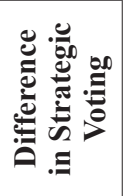 & 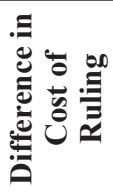 & 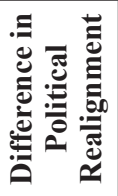 & 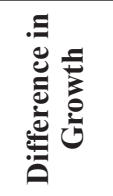 & 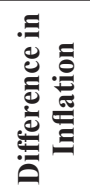 & 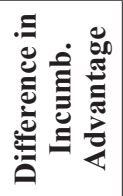 & 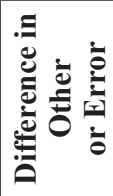 \\
\hline 2007 vs. 2 & 18 & & 00 & -1.06 & 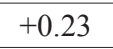 & 126 & 00 & 87 \\
\hline 2009 vs. 2007 & 10 & & +2.97 & -0.73 & & כנ & 0.00 & -1.41 \\
\hline 2011 vs.2009 & +19.63 & +5.59 & -0.27 & +0.23 & +10.14 & +0.86 & 0.00 & +3.08 \\
\hline
\end{tabular}

Source: Author's computations using figures given in table 2. 
Appendix Table. Political and economic conditions, and electoral outcomes: 1950-2011

\begin{tabular}{|c|c|c|c|c|c|}
\hline \multirow{2}{*}{\begin{tabular}{c}
\multicolumn{1}{c}{$\begin{array}{c}\text { Election } \\
\text { Date }\end{array}$} \\
Nov. 6,1983 \\
Mar. 25,1984
\end{tabular}} & \multirow{2}{*}{\begin{tabular}{|l|}
$\begin{array}{c}\text { Election } \\
\text { Type a }\end{array}$ \\
A \\
L
\end{tabular}} & \multirow{2}{*}{$\begin{array}{c}\begin{array}{c}\text { Provinces } \\
\text { covered } \\
\text { by the } \\
\text { election }\end{array} \\
67 \text { of } 67 \\
67 \text { of } 67\end{array}$} & \multirow{2}{*}{$\begin{array}{l}\begin{array}{l}\text { Incumbent } \\
\text { Parties }\end{array} \\
\\
\text { itary } \\
\text { AP }\end{array}$} & \multicolumn{2}{|c|}{$\begin{array}{c}\text { Vote Share } \\
(\%) \\
\text { Major All } \\
\text { Incumbent Incumbent } \\
\text { Party Parties }\end{array}$} \\
\hline & & & & 41.48 & 41.48 \\
\hline Sep. 28, 1986 & B & 10 of 67 & ANAP & 32.12 & 32.12 \\
\hline Nov. 29, 1987 & A & 67 of 67 & ANAP & 36.31 & 36.31 \\
\hline Mar. 26, 1989 & L & 71 of 71 & ANAP & 21.80 & 21.80 \\
\hline Oct. 20, 1991 & A & 74 of 74 & ANAP & 24.01 & 24.01 \\
\hline Mar. 27, 1994 & $\mathrm{~L}$ & 76 of 76 & DYP/SHP & 21.44 & 35.01 \\
\hline Dec. 24,1995 & A & 79 of 79 & DYP/CHP & 19.18 & 29.89 \\
\hline Apr. 18, 1999 & A & 80 of 80 & ANAP/DSP/DTP ${ }^{\mathrm{m}}$ & 13.22 & 35.99 \\
\hline Nov. 3, 2002 & A & 81 of 81 & DSP/MHP/ANAP & 1.22 & 14.71 \\
\hline Mar. 28, 2004 & $\mathrm{~L}$ & 81 of 81 & $\mathrm{AKP}$ & 41.67 & 41.67 \\
\hline July 22, 2007 & A & 81 of 81 & $\mathrm{AKP}$ & 46.58 & 46.58 \\
\hline Mar. 29, 2009 & $\mathrm{~L}$ & 81 of 81 & $\mathrm{AKP}$ & 38.39 & 38.39 \\
\hline June 12, 2011 & A & 81 of 81 & AKP & 49.83 & 49.83 \\
\hline May. 14,195 & A & 63 of 63 & CHP & 39. & 39.45 \\
\hline Sep. 16, 1951 & B & 17 of 63 & DP1 & 52.73 & 52.73 \\
\hline May 2, 1954 & A & 64 of 64 & DP1 & 57.61 & 57.61 \\
\hline Oct. 27,1957 & A & 67 of 67 & DP1 & 47.88 & 47.88 \\
\hline Oct. 15,1961 & A & 67 of 67 & Military ${ }^{g}$ & & \\
\hline Nov. 17, 1963 & $\mathrm{~L}$ & 67 of 67 & CHP/YTP/CKMP & 36.21 & 45.73 \\
\hline June 7, 1964 & $S$ & 26 of 67 & CHP & 40.85 & 40.85 \\
\hline Oct. 10,1965 & A & 67 of 67 & AP/CKMP/YTP/MP & 52.87 & 65.10 \\
\hline June 7, 1966 & $\mathrm{~S}+\mathrm{B}$ & 24 of 67 & AP & 56.49 & 56.49 \\
\hline June 2, 1968 & $\mathrm{~L}$ & 67 of 67 & AP & 49.06 & 49.06 \\
\hline Oct. 12, 1969 & A & 67 of 67 & AP & 46.53 & 46.53 \\
\hline Oct. 14, 1973 & A & 67 of 67 & AP/CGP & 29.82 & 35.08 \\
\hline Oct. 12,1975 & $\mathrm{~S}+\mathrm{B}$ & 27 of 67 & AP/MSP/CGP/MHP & 41.34 & $52.98^{\mathrm{j}}$ \\
\hline June 5, 1977 & A & 67 of 67 & AP/MSP/CGP/MHP & 36.88 & 53.73 \\
\hline Dec. 11, 1977 & $\mathrm{~L}$ & 67 of 67 & AP/MSP/MHP & 37.08 & 50.59 \\
\hline Oct. 14, 1979 & $\mathrm{~S}+\mathrm{B}$ & 29 of 67 & CHP/CGP/DP2 & 29.22 & $31.59^{\mathrm{k}}$ \\
\hline
\end{tabular}

Appendix table notes:

a ANational Assembly general election.

BNational Assembly by election.

S Senate election

LLocal (Provincial General Assembly) election.

$\mathrm{S}+\mathrm{BSenate}$ election plus National Assembly by election (only in provinces where no Senate election was held simultaneously). 
Continued Appendix Table. Political and economic conditions, and electoral outcomes: 1950-2011

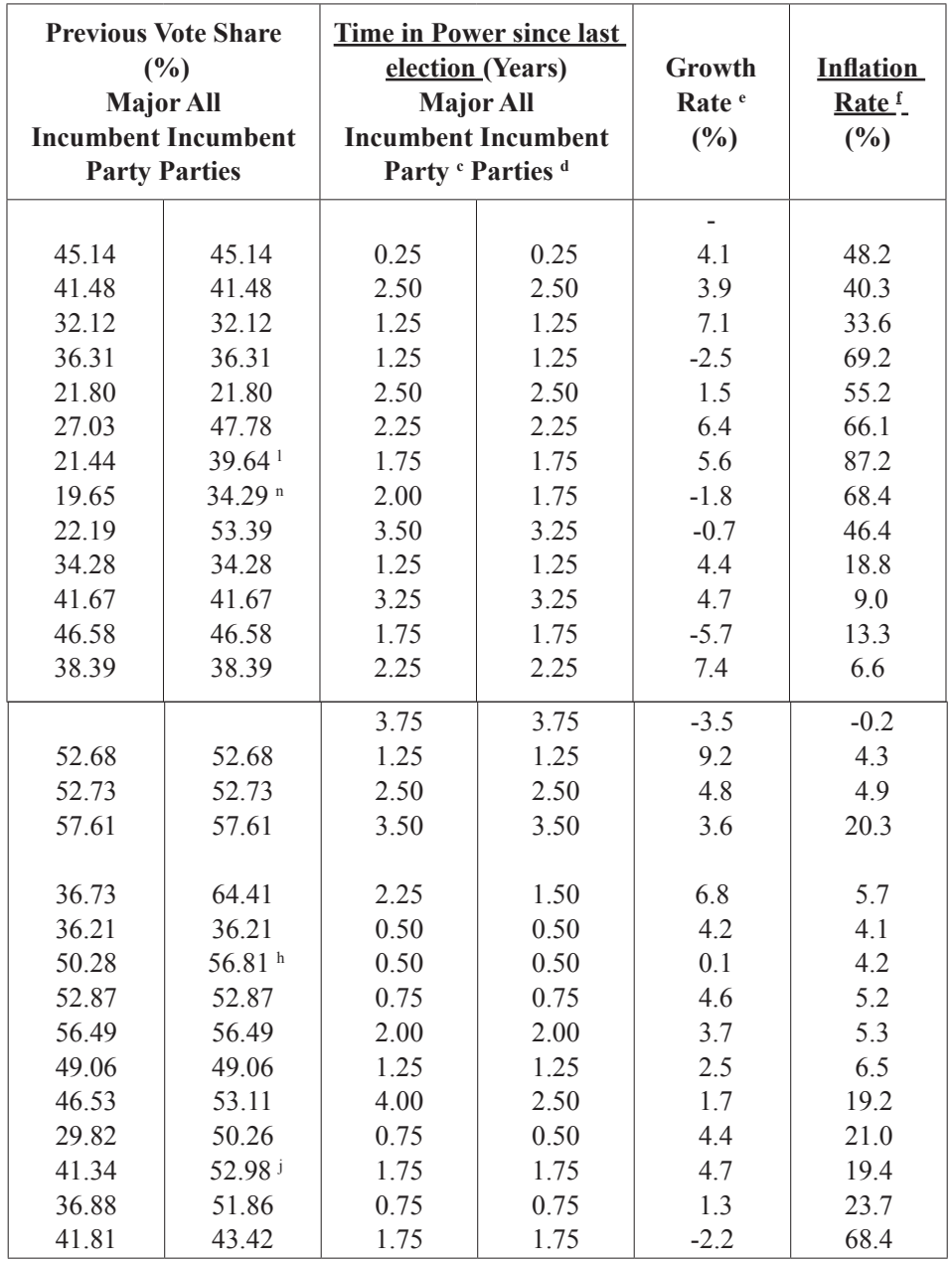

In instances when different types of elections are held simultaneously or almost simultaneously, the priority for inclusion in the sample was given first to the National Assembly general elections, next to the Provincial Council elections, then to the Senate elections, and last to the by elections. The Senate and by elections were given lower priorities because, unlike the National Assembly general elections and local elections, they did not cover the whole country. The Senate elections involved only a third of the provinces and only a third of the seats in the Senate that were subject to election. The coverage of by elections were even less, about 15-27 
percent of the provinces when they did not coincide with a Senate election. When the Senate and by elections were held simultaneously, their results were aggregated to increase the coverage of the country. In such aggregation, for provinces where the two elections overlapped, only the results of the Senate election is considered.

b The party listed first in the table is the major incumbent party. The Turkish acronyms used in the table and the parties they represent are as follows:

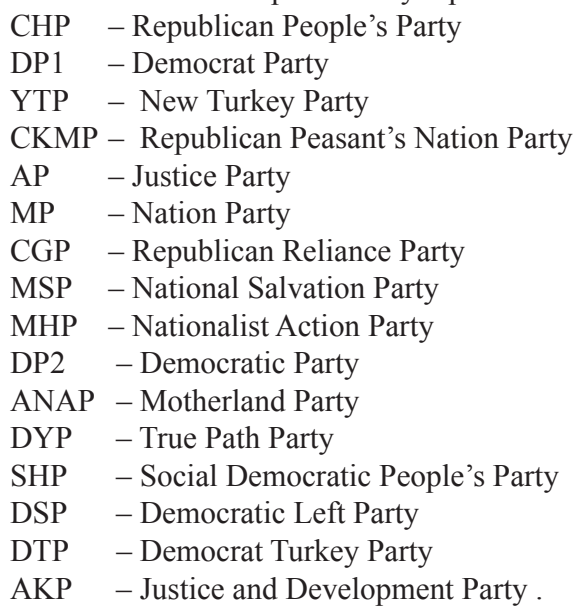

c $\quad 0.25$ times the number of quarters since last election during which the major incumbent party was in power majority of time, either alone or with other parties.

d 0.25 times the number of quarters since last election during which all incumbent parties were in power simultaneously majority of time, with or without other parties.

e The growth rate, $g_{t}$, is taken as the growth rate of per capita real GDP during the fourquarter period preceeding the election. The latter is obtained by adjusting the growth rate of real GDP during the four-quarter period before the election with the annual growth rate of the population during the year of the election if the election was held in the second half of the year and during the year before if the election was held in the first half of the year. The quarter of the election is included in the four-quarter period if the election was held in the second half of the quarter and not, if otherwise.

For the elections prior to 1989 , when quarterly data was not available, $g_{t}$ is computed as follows:

$\mathrm{g}_{\mathrm{t}}=\mathrm{m} \mathrm{G}_{\mathrm{t}}+(1-\mathrm{m}) \mathrm{G}_{\mathrm{t}-1}$

where $G_{t}$ and $G_{t-1}$ are the annual growth rates for the year in which the election was held, and the one prior to that.

$\mathrm{m}=0.00$ if the election is held between January 1 and February 14,

$\mathrm{m}=0.25$ if the election is held between February 15 and May 15,

$\mathrm{m}=0.50$ if the election is held between May 16 and August 15,

$\mathrm{m}=0.75$ if the election is held between August 16 and November 15,

$\mathrm{m}=1.00$ if the election is held between November 16 and December 31,

except for elections in 1965, 1975 and 1984, when $\mathrm{m}$ is taken as unity because the governments then were either not in power during the year preceding the election or were in power for less than half a quater.

For years 1948 and 1968 growth rate of per capita real GNP is substituted for missing growth rate figures for per capita real GDP.

f The inflation rate, $p_{t}$, is taken as the growth rate of the GDP implicit price deflator dur- 
ing the four-quarter period preceding the election. The quarter of the election is included in the four-quarter period if the election was held in the second half of the quarter and not if otherwise. For the elections prior to 1989 , when quarterly data was not available, $\mathrm{p}_{\mathrm{t}}$ is computed as weighted average of the annual inflation rates during the election year and the one before it, in a similar way the $\mathrm{g}_{\mathrm{t}}$ was computed as explained above.

For the years 1948, and 1968, rate of change in GNP deflator is substituted for missing figures for the rate of change in GDP deflator.

$g$ To increase the number of observations, Republican People's Party (CHP) was treated as the incumbent party in 1961 by Akarca and Tansel (2006) and Akarca (2009, 2010 and 2011) even though the military was in power. This party was allied with the military regime at the time and supported it or at least perceived by the public as such. Now that there are more data points at hand, 1961 election is dropped from the sample.

h Vote share of only AP, CKMP and YTP. MP did not enter the 1964 election.

j Vote share of only AP, MSP and MHP. CGP did not enter the 1975 election.

k Vote share of only CHP and CGP. DP2 did not enter the 1979 election.

1 Vote share of DYP, CHP and SHP in 1994. SHP merged with CHP in 1995. So SHP and CHP are treated as one party.

$\mathrm{m}$ A minority government formed by DSP was in power during the four months preceding the election but it was just a caretaker government. For that reason the coalition government in power prior to that for over eighteen months is taken as the incumbent.

n Vote share of only ANAP and DSP. DTP was formed in 1997 and thus did not enter the 1995 election.

Sources of data: The dates and the coverage of elections, and the make-up of governments and their time in power, are determined using the information given in Tuncer $(2002,2007$, and 2009) and Tuncer and Kasapbaş (2004).

All vote shares are computed by the author, using the data provided by Tuncer (2002, 2007, and 2009) and Tuncer and Kasapbaş (2004) for the elections held between 1961 and 2009, and by the Turkish Statistical Institute (TurkStat) of the Republic of Turkey, for the elections between 1950 and 1957 and in 2011. In aggregating the Grand National Assembly By and Senate elections held in 1975 and 1979, the province level vote data provided by TurkStat was also utilized.

The growth rates are computed by the author, as explained in note (e) above, using the data provided by the TurkStat for all years except 1948 and 1968. For latter two years, per capita real GNP growth rate is substituted for the missing growth rate in per capita real GDP. In computing the former, the population growth rate, provided by the TurkStat, and the real GNP growth rate, provided by the State Planning Organization (SPO) of the Republic of Turkey are utilized. The GDP series, from which the annual growth rates are obtained, is 1987 based for the years prior to 1998, and 1998 based for years after 1999.

The inflation rates are computed by the author, as explained in note (f) above, using the data provided by the TurkStat for all years except 1948 and 1968, for which the rate of change in GNP price deflator was used instead. The rate of change in GNP deflator is provided by the SPO. 


\section{Literature}

Akarca A. T. (2011), A Prediction for AKP's Nationwide Vote Share in the 12 June 2011 Turkish Parliamentary Election, „İktisat İşletme ve Finans” 26 (302), pp. 53-74.

Akarca A. T. (2010), Analysis of the 2009 Turkish Election Results from an Economic Voting Perspective, „European Research Studies Journal” 13, 2010, pp. 3-38.

Akarca A. T. (2009), A Prediction for AKP's Nationwide Vote Share in the 29 March 2009 Turkish Local Elections, „İktisat İşletme ve Finans” 24 (276), pp. 7-22.

Akarca A. T. and Başlevent, C. (2009), Inter-party Vote Movements in Turkey: The sources of AKP Votes in 2007, „İktisat İşletme ve Finans” 24 (285), pp. 32-47.

Akarca A. T. and Tansel, A. (2007), Social and Economic Determinants of Turkish Voter Choice in the 1995 Parliamentary Election, „Electoral Studies” 26, pp. 633-647.

Akarca A. T. and Tansel A. (2006), Economic Performance and Political Outcomes: An Analysis of the Turkish Parliamentary and Local Election Results Between 1950 and 2004, Public Choice 129, pp. 77-105.

Başlevent C. and Akarca A. T. (2009), Micro Evidence on Inter-Party Vote Movements in Turkey: Who Voted for AKP in 2002?, Paper presented at the 5th ECPR General Conference, Potsdam, Germany, 10-12 September 2009.

Chang E. C. C., Golden M. A. and Hill, S. J. (2010), Legislative Malfeasance and Political Accountability, World Politics 62, pp. 177-220.

Durbin J. (1970), Testing for Serial Correlation in Least Squares Regression When Some of the Regressors Are Lagged Dependent Variables, „Econometrica” 38, pp. 410-421.

Ferraz C. and Finan, F. (2008), Exposing Corrupt Politicians: The Effect of Brazil's Publicly Released Audits on Electoral Outcomes, „Quarterly Journal of Economics” 123, pp. 703-745 .

Lewis-Beck M. S . and Paldam, M. (2000), Economic Voting: An Introduction, „Electoral Studies" 19, pp. 113-121.

Lewis-Beck M. S. and Stegmaier M., (2000), Economic Determinants of Electoral Outcomes, „Annual Review of Political Science” 3, pp. 183-219.

Tuncer E. (2009), 29 Mart 2009 İl Genel Meclisi ve Belediye Seçimleri: Sayısal ve Siyasal Değerlendirme (29 March 2009 Provincial General Council and Municipality Elections: A Quantitative and Political Evaluation). TESAV: Ankara, Turkey

Tuncer E. (2007), 22 Temmuz 2007 Milletvekili Genel Seçimleri: Sayısal ve Siyasal Değerlendirme (22 July 2007 Elections for Members of Parliament: A Quantitative and Political Evaluation). TESAV: Ankara, Turkey

Tuncer E. and Kasapbaş C. (2004), 28 Mart 2004 İl Genel Meclisi ve Belediye Seçimleri: Sayısal ve Siyasal Değerlendirme (28 March 2004 Provincial General Assembly and Municipality Elections: A Quantitative and Political Evaluation). TESAV: Ankara, Turkey.

Tuncer E. (2002), Osmanlı'dan Günümüze Seçimler: 1877-1999 (Elections From the Ottomans to the Present: 1877-1999). TESAV: Ankara, Turkey.

White H. (1980), "A Heteroskedasticity-Consistent Covariance Matrix Estimator and a Direct Test for Heteroskedasticity, „Econometrica” 48, pp. 817-838. 
